\author{
地盤構造モデルに基づく伝達関数を用いた任意震源による \\ 長周期地震動の予測手法 \\ PREDICTION METHOD OF LONG-PERIOD GROUND MOTION \\ FOR ARBITRARY SEISMIC SOURCE \\ USING TRANSFER FUNCTION BASED ON SOIL STRUCTURE MODEL
}

\author{
平井 敬*, 福 和 伸 $*^{* * *}$ \\ Takashi HIRAI and Nobuo FUKUWA
}

\begin{abstract}
A new method to predict a long-period ground motion due to arbitrary seismic source was developed. In the method, the ground motion due to an earthquake is generated from the ground motion record due to other earthquake by using the transfer function defined as the spectral ratio between the theoretical ground motions due to each earthquake. The theoretical ground motions are simulated based on a soil structure model by 3D finite difference method. In addition, a technique to compute the Green's functions giving the ground motions at a station by arbitrary seismic sources based on the reciprocity theorem is used in order to reduce calculation load. Applying the new method to three earthquakes, it was suggested that the ground motion record of a small earthquake is accurately scaled up to that of a large earthquake.
\end{abstract}

Keywords : Ground motion prediction, Soil structure model, Transfer function, Long-period ground motion, Finite difference method, Reciprocity theorem 地震動予測, 地盤構造モデル，伝達関数，長周期地震動，有限差分法，相反定理

\section{1. はじめに}

日本列島は世界でもまれな 4 枚のプレートが収束する地域に位置 しており，しばしば大地震による被害を生じてきた．特に，南方の フィリピン海プレートがユーラシアプレートの下に沈み込む南海卜 ラフにおいては，およそ 100 年から 150 年程度の周期でマグニチュ ード 8 クラスの巨大地震が発生してきた. 南海トラフで発生した前 回の大地震は 1944 年の東南海地震および 1946 年の南海地震であり, 次の巨大地震の発生が次第に切迫してきている. 近年では, 2011 年 東北地方太平洋沖地震の発生を受けて, 中央防災会議が南海トラフ

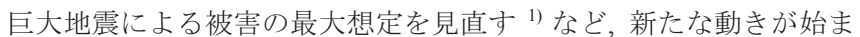
っている.

巨大地震に特有の問題のひとつとして, 長周期地震動が挙げられ る.これは，地震動に含まれる周期数秒以上の成分が，超高層建物 や長大橋の振動, あるいは石油タンクのスロッシングをよく励起す るという問題である. 2011 年東北地方太平洋沖地震では, 大阪市此 花区に位置する大阪府咲洲庁舎が地盤と共振を起こし, 片振幅 137 $\mathrm{cm}$ にもなる非常に大きな摇れを生じた ${ }^{2), 3)}$.これは, 建物の固有周 期と地震動の卓越周期が一致したために生じた現象であると考えら
れる. 通常，卓越周期は一定のものとして扱われることが多いが， 実際には地震ごとに異なる值を取る場合のあることが報告されてい る. 例えば, 座間 ${ }^{4)}$, 植竹 ${ }^{5)}$, 湯沢・南雲 ${ }^{6)}$ は東京における長周期地 震動の卓越周期が震源の位置に依存することを示し，寺島・他 ${ }^{7)}$ は 大阪府咲洲庁舎に近い KiK-net 此花観測点について, 地震動の卓越 周期が $6 \mathrm{~s} \sim 7 \mathrm{~s}$ 程度の範囲で変動することを指摘している.

以上のように，長周期地震動への対策が重要であるが，その予測 においては, 今なお課題が残っている. 経験的グリーン関数法 ${ }^{8)}$ は, 想定地震の震源近傍で発生した中小地震による波形記録を要素とし て，これを多数重㸚合わせることで大地震による地震動波形を予測 するものであり，現在のところもっとも精度よく地震動を予測する ことができる手法であると考えられている。しかしながら，現在の 波形合成時の距離補正は，主として実体波を仮定しており，長周期 地震動を論ずる際に特に問題となる表面波の扱いには課題が残って いる. 寸なわち，実体波は震源からの距離に反比例して振幅が減少 するが, 表面波は距離の平方根に反比例して振幅が減少することを 適切に考慮していない. また, 現在の方法では地震モーメントの違 いと震源からの地震波の放射特性を考慮して波形合成を行うが，複
$*$ 名古屋大学大学院環境学研究科 助教 $\cdot$ 博士 (工学 $)$

** 名古屋大学減災連携研究センター 教授·工博
Assist. Prof., Graduate School of Environmental Studies, Nagoya University, Dr. Eng. Prof., Disaster Mitigation Research Center, Nagoya University, Dr. Eng. 
雑な地下構造に起因する波形の変化を反映することは困難である.

高橋・他は, 中小地震による波形記録を用いて精度よく地震動を 計算することが可能な経験的グリーン関数法と, 面的な地震動予測 が可能な理論的手法を組み合わせることで, 面的に精度よく地震動 予測を行うという，擬似経験的グリーン関数法を提案した ${ }^{9}$. これ は, 地震動を予測する対象地点と, その近傍にある中小地震による 波形記録が得られている地点それぞれについて, 中小地震による地 震動を理論計算によって求め, そのスペクトル比を伝達関数として 中小地震による波形記録に乗ずることで, 予測地点での中小地震に よる地震動波形を推定するというものである.

本論文では, 経験的グリーン関数法における地震動の補正に擬似 経験的グリーン関数法の考え方を援用して地震動予測を行う方法を 提案する. 有限差分法による波形シミュレーションは, 地震動の周 期特性や地点間の振幅・継続時間の相対的な関係をおおむね説明で きると考えられている ${ }^{9}$. これを利用して, 擬似経験的グリーン関 数法では, ひとつの地震による地震動を 2 地点で計算し, そのスペ クトル比を伝達関数として観測点位置の違いによる地震動の差異を 表現する.一方, 本手法では, 2 つの地震による地震動を共通の観測 点で計算し, そのスペクトル比を伝達関数として震源位置・パラメ 一タの違いによる地震動の差異を表現する. この方法は, 経験的グ リーン関数法などの波形合成法において, 中小地震の波形記録を想 定地震の要素地震動に補正する際に利用することができる. これに より, 理論的手法において地盤構造を完全にモデル化できていない としても，それによるずれを観測記録で補正することができると考 えられる. また, 従来は実体波を仮定して行っていた地震動の補正 を, 波動の全相を考慮して行うことが可能となる。つまり, P 波・S 波・表面波の走時・距離減衰特性・放射特性などの諸量を, 各相で 理論的に評価して補正することができるようになる.

以降, 第 2 章において経験的グリーン関数法・擬似経験的グリー ン関数法・本提案手法の概要を説明する. 第 3 章では本手法を適用 したモデルを示し, 第 4 章において従来法と比較しながら本手法の 妥当性を検証する.

\section{2. 理論}

\section{1 経験的グリーン関数法の概要}

本論文で提案する伝達関数を用いた地震動の補正方法は, 主とし て波形合成による地震動予測への応用を指向している. そのため, 本節においてその概要を説明する.

経験的グリーン関数法は, 想定する大地震の震源断層を小さな要 素断層の集合体として表現し, まず各要素に起因する地震動を予測 して，これを破壊伝播による時間遅れを考慮しながら足し合わせる ことにより, 大地震による地震動を予測する方法である. 計算方法 としては，以下のように定式化される。

$$
u_{i}^{\mathrm{syn}}(t)=\sum_{j=1}^{n} u_{i j}^{\mathrm{elem}}\left(t-t_{j}^{\mathrm{del}}\right)
$$

ここで $u_{i}^{\mathrm{syn}}(t)$ は合成された地震動の $i$ 成分, $u_{i j}^{\mathrm{elem}}\left(t-t_{j}^{\mathrm{del}}\right)$ は要素断層 $j$ から発せられる地震動の $i$ 成分を表す. $t_{j}^{\mathrm{del}}$ は要素断層 $j$ による地震 動が観測点に到達するまでの時間遅れを表しており，下記のように
計算される

$$
t_{j}^{\mathrm{del}}=t_{j}^{\mathrm{rup}}+\frac{r_{j}-r^{\mathrm{seed}}}{V_{\mathrm{S}}}
$$

ここで $t_{j}^{\text {rup }}$ は要素断層 $j$ の破壊時刻, $r_{j}$ と $r^{\text {seed }}$ はそれぞれ観測点から

見た要素断層と中小地震の震源までの距離， $V_{\mathrm{S}}$ は $\mathrm{S}$ 波速度である 大地震による地震動を構成する波動のうち, $\mathrm{S}$ 波をもっとも重要と 考えて, 式 (2) では震源距離による到達時間の差を $\mathrm{S}$ 波速度を用い て補正している.

式 (1) における要素断層から発せられる地震動を推定する方法 には，様々な方法が提案されている。例えば, Irikura (1983) は中小 地震による地震動を複数回繰り返すことで大地震の要素断層による 地震動を表現した ${ }^{10}$. 他に, 短周期成分の適合性に優れた田中・他 の方法 ${ }^{11)}$ や, Irikura (1983) を改良した Irikura (1986) の方法 ${ }^{12)}$ があ るが, 本論文では壇・佐藤の方法 ${ }^{13)}$ を取り上げる.

壇・佐藤の方法では, 中小地震による地震動記録に対して $\omega^{-2}$ スペ クトルに基づくスケールファクターを乗ずることで, 要素断層から 発せられる地震動を推定する.

$$
U_{i j}^{\text {elem }}(\omega)=\frac{r^{\text {sed }} A_{i j}^{\text {elem }}(\omega) S_{j}^{\text {elem }}(\omega)}{r_{j}^{\text {elem }} A_{i}^{\text {seed }}(\omega) S^{\text {seed }}(\omega)} U_{i}^{\text {seed }}(\omega)
$$

ここで $A_{i}(\omega)$ は震源と観測点との位置関係・走向・傾斜・すべり角 によって定まる地震動の放射特性， $S(\omega)$ は震源スペクトルを表す. これ以降, 角振動数を変数とするアルファベット大文字で書かれる 関数は, 対応する小文字の時間領域の関数のフーリエ変換を表すも のとする.ただし，放射特性の補正をそのまま当てはめると，極端 に大きな，または小さな計算結果となることがあり，壇・佐藤の事 例では放射特性の補正を行っていない，本論文においても，放射特 性の補正を考慮することはせず，すべての震源・要素断層と観測点 の組合せについて $A_{i}(\omega)=1$ とする. 震源スペクトルには, ひとつの コーナー振動数を有する $\omega^{-2}$ スペクトルを用いる.

$$
S(\omega)=\frac{M_{0}}{\left(1+i \omega / \omega_{\mathrm{c}}\right)^{2}}
$$

ここで $M_{0}$ は地震モーメント, $\omega_{\mathrm{c}}$ はコーナー角振動数 ( = コーナー 振動数 $\times 2 \pi)$ を表す.

なお, 本来の壇・佐藤の方法では, 想定地震に対してはふたつの コーナー振動数を有する $\omega^{-2}$ スペクトルを用いている. しかしなが ら, 壇・佐藤の方法の骨子は震源スペクトルの比を用いて地震動を 補正することにある. 本論文では, 想定地震に対してもひとつのコ 一ナー振動数を有する $\omega^{-2}$ スペクトルを用いることとし, 式 (4) の 震源スペクトルを採用した。

壇・佐藤の方法は, 本来は周期数秒より短い地震動を予測するこ とを目的としている.しかし, 長周期地震動を含めたハイブリッド グリーン関数法において波形合成の際に用いられることや，スケー ルファクターによる地震動の補正は, 後述する伝達関数による地震 動の補正を簡便に行っていると解釈することが可能であることから， 本論文において比較対象とする.

\section{2 伝達関数による地震動の補正}

本論文で提案する地震動の補正方法は，高橋・他による擬似経験 的グリーン関数法の考え方を震源側に拡張したものである. 図 1 に, 


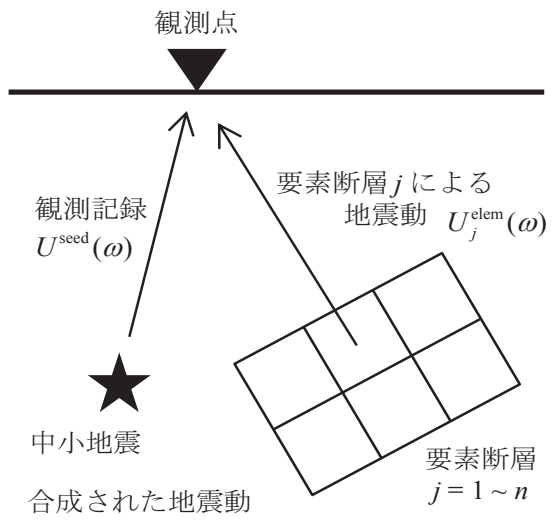

$U(\omega)=\sum_{j=1}^{n} \frac{r^{\text {seed }} A_{j}^{\text {elem }} S_{j}^{\text {elem }}(\omega)}{r_{j}^{\text {elem }} A^{\text {sed }} S^{\text {seed }}(\omega)} U^{\text {seed }}(\omega) e^{i \omega \tau_{j}}$

(a) 経験的グリーン関数法

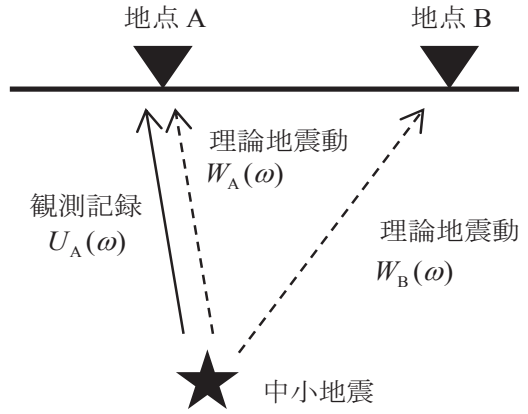

地点 $\mathrm{B}$ での中小地震による地震動

$$
U_{\mathrm{B}}(\omega)=\frac{W_{\mathrm{B}}(\omega)}{W_{\mathrm{A}}(\omega)} U_{\mathrm{A}}(\omega)
$$

(b) 擬似経験的グリーン関数法

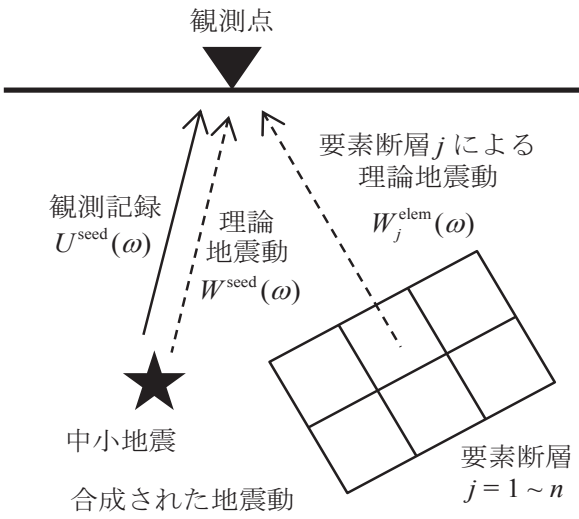

$U_{j}^{\text {elem }}(\omega)=\sum_{j=1}^{n} \frac{W_{j}^{\text {elem }}(\omega)}{W^{\text {seed }}(\omega)} U^{\text {seed }}(\omega)$

(c) 本提案手法

図 1 (a) 経験的グリーン関数法, (b) 擬似経験的グリーン関数法, (c) 本提案手法の模式図

従来の経験的グリーン関数法, 高橋・他による擬似経験的グリーン 関数法, および本提案手法の模式図を示す.

経験的グリーン関数法は, 中小地震による地震動記録が得られて いる地点においてのみ適用可能な手法である。これを地震動記録が 存在しない地点に対しても適用しようとすると, 何らかの方法でそ の地点に対する中小地震による地震動を推定する必要がある. 高 橋-他の擬似経験的グリーン関数法では, 3 次元有限差分法による理 論地震動のスペクトル比を伝達関数として用いることで, これを実 現した.

これに対して本論文においては, 理論地震動のスペクトル比とし て定義される伝達関数を, 観測点の相違ではなく震源の相違に対し て適用する. 本手法を用いて波形合成を行う場合, 大地震による地 震動は次式で表される.

$$
u_{i}^{\mathrm{syn}}(t)=\sum_{j=1}^{n} u_{i j}^{\text {elem }}\left(t-t_{j}^{\mathrm{rup}}\right)
$$

要素断層から発せられる地震動 $u_{i j}^{\mathrm{elem}}(t)$ は下記のように推定する.

$$
U_{i j}^{\mathrm{elem}}(\omega)=\frac{W_{i j}^{\text {elem }}(\omega)}{W_{i}^{\text {seed }}(\omega)} U_{i}^{\text {sed }}(\omega)
$$

ここで, $W_{i j}^{\mathrm{elem}}(\omega)$ と $W_{i}^{\mathrm{sed}}(\omega)$ はそれぞれ $j$ 番目の要素断層と中小地

震による地震動を理論計算によって求めたものである. 経験的グリ ーン関数法の式 (1) においては, 要素断層による地震動を足し合わ せる際に, 式 (2) のように要素断層の破壊時刻と走時差を考慮して いるのに対し, 式 (5) においては走時差を表す項が存在しない。こ れは, 式 (6) に現れる各グリーン関数の位相部分に走時の情報が含 まれているため, スペクトル比 (伝達関数) の位相部分には走時の 差が組み込まれていることによる. また, 壇・佐藤の補正方法の式 (3) においては, 震源距離・放射特性・震源スペクトルの比を作用さ せて地震動を補正しているが, 式 (6) においては単純に理論地震動 のスペクトル比を乗ずるだけとなっている。こちらも，距離減衰・ 放射特性・震源時間関数の影響が, すべて理論地震動のスペクトル に含まれているため, 式の上では非常に単純な形となる.

なお, 式 (6) の伝達関数は, 分母のスペクトルが 0 に近い值とな
る振動数においては極端に大きな值となる。これを避けるために, 本論文ではそれぞれのスペクトルにバンド幅 $0.05 \mathrm{~Hz}$ の Parzen ウィ ンドウを施してから除算を行った.

\section{3 相反性を用いたグリーン関数の計算}

本論文で提案する手法を波形合成法に適用する場合，非常に多く の要素断層による理論地震動を, 別々に計算する必要がある. 不整 形な地盤モデルを使用する場合, 理論的に地震動を計算する手法と しては 3 次元有限差分法が有力であるが，この方法は大きな計算機 資源と長い計算時間を要する. そのため, 要素断層での破壊を力源 とする通常の計算方法では, 極めて効率が悪い。このような場合, グリーン関数の相反性を利用すると, 計算量を大きく削減すること が可能である. 以下に，平井・福和による相反性を利用したグリー ン関数の計算方法 ${ }^{14)}$ を概説する.

地盤を等方線形弾性体とした場合, 地盤内の一点 $\xi$ に時刻 $\tau$ に $p$ 方向に単位のインパルスカを与えたことによって, $\boldsymbol{x}$ 地点にて時刻 $t$ に生じる変位の $i$ 成分を $G_{i p}(\boldsymbol{x}, t ; \boldsymbol{\xi}, \tau)$ とする。 このとき,一般に $G_{i p}(\boldsymbol{x}, t ; \boldsymbol{\xi}, \tau)=G_{i p}(\boldsymbol{x}, t-\tau ; \boldsymbol{\xi}, 0)$ であり, かつ次式が成立する.

$$
G_{i p}(\boldsymbol{x}, t-\tau ; \boldsymbol{\xi}, 0)=G_{p i}(\boldsymbol{\xi}, t-\tau ; \boldsymbol{x}, 0)
$$

これがグリーン関数の相反性であり, 震源と観測点を入れ替えても, 同じグリーン関数が得られることを示している. 地震による変位波 形は下記の式で与えられる ${ }^{15)}$.

$$
u_{i}(\boldsymbol{x}, t)=\sum_{p=1}^{3} \sum_{q=1}^{3} \int_{-\infty}^{t} \int_{\Omega} \frac{\partial G_{i p}(\boldsymbol{x}, t-\tau ; \boldsymbol{\xi}, 0)}{\partial \xi_{q}} m_{p q}(\boldsymbol{\xi}, \tau) d V d \tau
$$

ここで $\Omega$ は震源域の空間的な広がりを示しており, $m_{p q}(\xi, \tau)$ はモ ーメントテンソル密度の累積解放量を表す関数である. 式 (8) に対 してグリーン関数の相反性 (7) を代入すると, 次式を得る.

$$
u_{i}(\boldsymbol{x}, t)=\sum_{p=1}^{3} \sum_{q=1}^{3} \int_{-\infty}^{t} \int_{\Omega} \frac{\partial G_{p i}(\boldsymbol{\xi}, t-\tau ; \boldsymbol{x}, 0)}{\partial \xi_{q}} m_{p q}(\boldsymbol{\xi}, \tau) d V d \tau
$$

ここで, 波形合成に用いる要素断層を点震源として扱うと, 震源域 に関する積分を省略することができ，次式のようになる．

$$
u_{i}(\boldsymbol{x}, t)=\sum_{p=1}^{3} \sum_{q=1}^{3} \int_{-\infty}^{t} \frac{\partial G_{p i}(\boldsymbol{\xi}, t-\tau ; \boldsymbol{x}, 0)}{\partial \xi_{q}} M_{p q}(\boldsymbol{\xi}, \tau) d \tau
$$




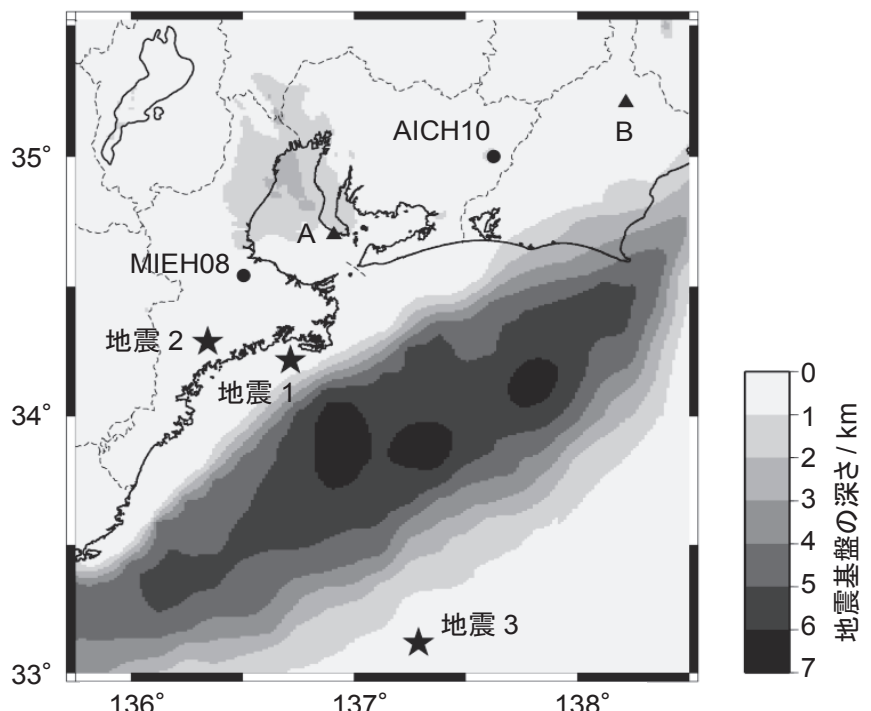

(a) 地盤構造モデル (地震基盤深さ) と震源·観測点

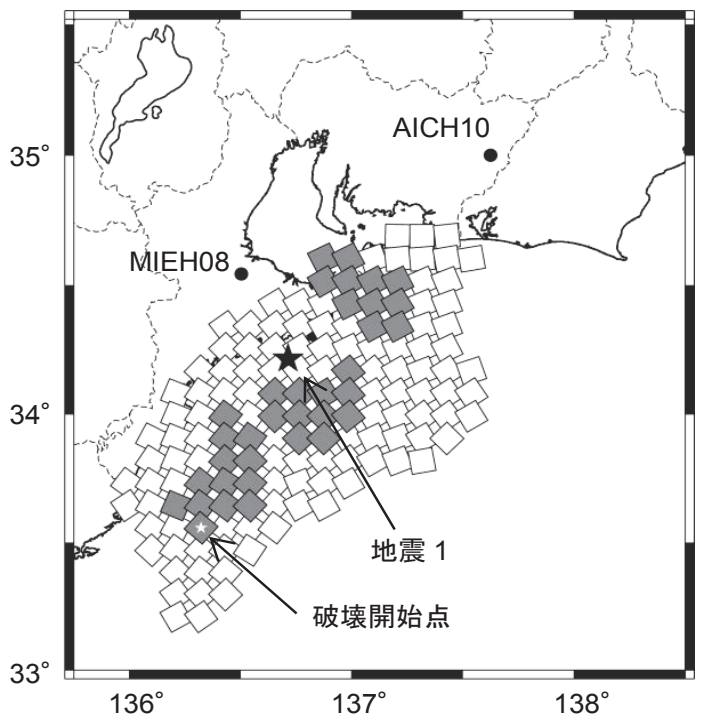

(b) 東南海地震の震源断層モデル

図 2 提案手法の検討に用いた地盤構造モデル (a) と震源モデル (b)
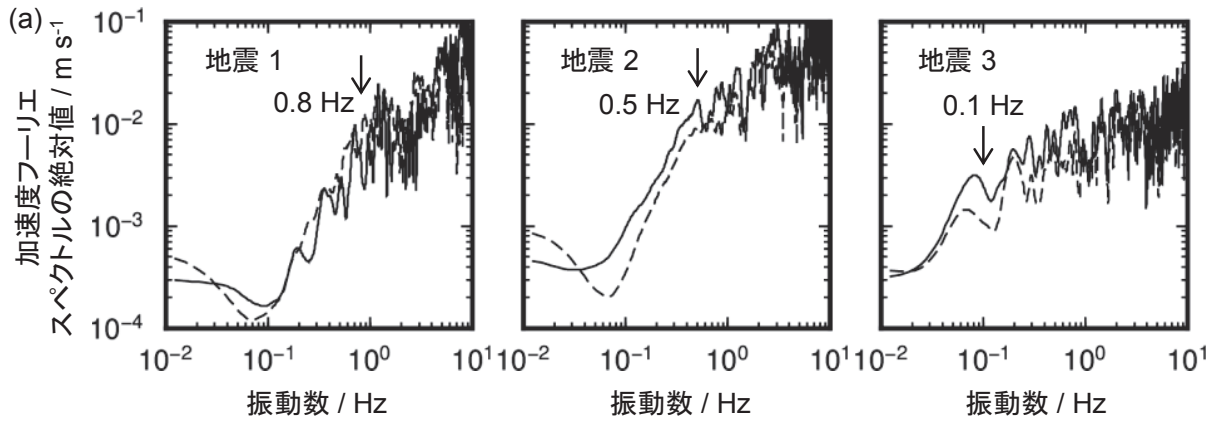

(b)

図 3 (a) MIEH08 での地震動記録のフーリエスペクトルとコーナー振動数の読取値（b) 震源時間関数

ここで $M_{p q}(\xi, t)$ は要素断層のモーメントテンソルの累積解放量を表 す関数である. 式 (10) において, $\partial G_{p i}(\boldsymbol{\xi}, t-\tau ; \boldsymbol{x}, 0) / \partial \xi_{q}$ は地点 $\boldsymbol{x}$ に て $i$ 方向にインパルスカを作用させたときに地点 $\boldsymbol{\xi}$ に生じる変位の $p$ 成分の $q$ 方向の変化率を表すが，これはすぐに歪みテンソルの $p q$ 成分に変換できる. 本研究においては, 有限差分法の計算を行う際 に応力テンソルを出力しておき, 下記の応力 $(\sigma)$ 一歪み $(\varepsilon)$ 関係を 用いて歪みテンソルを計算する.

$$
\sigma_{i j}=\delta_{i j} \lambda \sum_{k=1}^{3} \varepsilon_{k k}+2 \mu \varepsilon_{i j}
$$

ここで, $\delta_{i j}$ はクロネッカーのデルタ, $\lambda$ と $\mu$ はラメの定数である.

式 (10) より, 観測点にインパルスカを作用させ, 震源となる点 すべてで歪みテンソルの時刻歴を記録しておけば，これが各震源に おけるモーメントテンソルの各成分による観測点での変位を表すグ リーン関数に等しいことが分かる.

観測点が $N$ 個あり，想定す心゙き震源が $M$ 個ある場合を考える。モ ーメントテンソルは 3 次元対称行列の形になっており, 独立成分の 数は 6 である. 通常の有限差分法の計算によって完全なグリーン関 数のセットを得るために必要な計算回数は $6 M$ となる. 対して, 相 反定理を用いる場合，同じ結果を得るために必要な計算回数は $3 N$ となる，本論文では，波形合成を行うことを前提にしているため， 想定すべき震源の数 $M$ は大きい. 対して, 地震動の面的予測に言及 しなければ, 観測点の数 $N$ は小さい. そのため, 本論文のような事
例に対しては，相反定理を利用してグリーン関数を計算することで， 計算量の大幅な削減が可能となる.

3. モデルとデータ

本論文においては，まず伝達関数を用いた地震動の補正について 妥当性を検証し，次にこれを波形合成法に適用した例を示寸

図 2 (a)に, 伝達関数による地震動の補正の妥当性を検証するた めに用いたモデルを示す. 図 2 (a) において, 色の濃淡は地震基盤の 深さ分布, 星印はサンプルとして取り上げた地震の震央, 丸印は地 震動の検証に用いた観測点を示す．地盤構造モデルとしては，堀 川・他による中京地域の深部地下構造モデル ${ }^{16)}$ を用いた. 表 1 に地 盤構造モデルの各層の物性值を示寸. 本来のモデルでは表層は $\mathrm{S}$ 波 速度 $100 \mathrm{~m} \mathrm{~s}^{-1}$ の層までモデル化してあるが, 本論文においては長周 期成分を主に扱うため, $\mathrm{S}$ 波速度 $400 \mathrm{~m} \mathrm{~s}^{-1}$ の工学的基盤面までの考 慮とし，それより浅い層には，工学的基盤面と同じ物性值を与えた。 表 2 に, サンプルとして取り上げた 3 地震の諸元を示す. 観測点は KiK-net 松阪 (MIEH08) と KiK-net 鳳来 (AICH10) とした。これら の選定は, 震源同士の距離が近い組合せ (地震 1 と地震 2), 遠い組 合せ (地震 1 と地震 3), および震源と観測点との距離が近いもの (MIEH08) と遠いもの (AICH10) を選び取るようにした. 表 2 に示 した諸元のうち，震源位置は気象庁による決定值を用いた。また， コーナー振動数は図 3 (a) に示寸 MIEH08 における各地震による地 
表 1 地盤構造モデルの各層の物性值

\begin{tabular}{|c|c|c|c|c|c|}
\hline 地質 & 層番号 & $\begin{array}{c}\text { 密度 } \\
/ \mathrm{kg} \mathrm{m}^{-3}\end{array}$ & $\begin{array}{c}\mathrm{P} \text { 波速度 } \\
/ \mathrm{km} \mathrm{s}^{-1}\end{array}$ & $\begin{array}{c}\mathrm{S} \text { 波速度 } \\
/ \mathrm{km} \mathrm{s}^{-1}\end{array}$ & $\begin{array}{l}\text { 基淮 } \\
\mathrm{Q} \text { 值 }\end{array}$ \\
\hline \multirow[t]{8}{*}{ 第四系 } & 1 & 1.88 & 1.70 & 0.40 & 80 \\
\hline & 2 & 1.92 & 1.77 & 0.50 & 100 \\
\hline & 3 & 1.95 & 1.86 & 0.60 & 120 \\
\hline & 4 & 1.99 & 1.94 & 0.70 & 140 \\
\hline & 5 & 2.03 & 2.03 & 0.80 & 160 \\
\hline & 6 & 2.06 & 2.13 & 0.90 & 180 \\
\hline & 7 & 2.10 & 2.23 & 1.00 & 200 \\
\hline & 8 & 2.13 & 2.33 & 1.10 & 220 \\
\hline \multirow[t]{12}{*}{ 東海層群 } & 9 & 1.88 & 1.54 & 0.40 & 80 \\
\hline & 10 & 1.95 & 1.80 & 0.50 & 100 \\
\hline & 11 & 2.00 & 2.00 & 0.60 & 120 \\
\hline & 12 & 2.05 & 2.10 & 0.70 & 140 \\
\hline & 13 & 2.07 & 2.20 & 0.80 & 160 \\
\hline & 14 & 2.10 & 2.30 & 0.90 & 180 \\
\hline & 15 & 2.15 & 2.40 & 1.00 & 200 \\
\hline & 16 & 2.13 & 2.40 & 1.10 & 220 \\
\hline & 17 & 2.16 & 2.55 & 1.20 & 240 \\
\hline & 18 & 2.20 & 2.72 & 1.30 & 260 \\
\hline & 19 & 2.23 & 2.90 & 1.40 & 280 \\
\hline & 20 & 2.26 & 3.08 & 1.50 & 300 \\
\hline 豊橋 C 層 & 21 & 1.99 & 2.10 & 0.70 & 140 \\
\hline \multirow[t]{5}{*}{ 中新統 } & 22 & 2.13 & 2.88 & 1.10 & 220 \\
\hline & 23 & 2.20 & 2.70 & 1.30 & 260 \\
\hline & 24 & 2.25 & 3.00 & 1.50 & 300 \\
\hline & 25 & 2.30 & 3.20 & 1.70 & 340 \\
\hline & 26 & 2.34 & 3.79 & 1.80 & 360 \\
\hline $\mathrm{D}$ 層 & 27 & 2.37 & 4.00 & 1.90 & 380 \\
\hline \multirow[t]{5}{*}{ 地震基盤 } & 28 & 2.35 & 3.50 & 2.00 & 400 \\
\hline & 29 & 2.42 & 3.64 & 2.10 & 400 \\
\hline & 30 & 2.45 & 4.20 & 2.40 & 400 \\
\hline & 31 & 2.60 & 5.00 & 2.90 & 400 \\
\hline & 32 & 2.63 & 5.00 & 3.20 & 400 \\
\hline \multirow[t]{2}{*}{ 上部地殼 } & 33 & 2.70 & 5.80 & 3.40 & 400 \\
\hline & 34 & 2.80 & 6.40 & 3.80 & 400 \\
\hline マントル & 35 & 3.20 & 7.50 & 4.50 & 500 \\
\hline 海洋地殼 & 36 & 2.90 & 6.80 & 4.00 & 300 \\
\hline
\end{tabular}

震動のフーリエスペクトルから目視によって決定した. 地震 1,2 の 走向・傾斜・すべり角・地震モーメントは, 震源から近い岩盤観測 点である MIEH08 での地震動観測記録をおおむね再現できるように 設定した. ただし地震 3 の震源メカニズムについては, 防災科学技 術研究所の F-net によるもの ${ }^{17)}$ を用いた. 震源時間関数には, 図 3 (b) に示すものを用いた. これは $\omega^{-2}$ 型震源スペクトルをフーリエ逆 変換したものであり, 図ではコーナー振動数で規格化して示した。 図 2 (b) には, 伝達関数による地震動の補正を波形合成法に適用寸 るにあたって使用した震源断層モデルを示した. 想定地震として
表 2 サンプルとして用いた地震の諸元

\begin{tabular}{cccc}
\hline & 地震 1 & 地震 2 & 地震 3 \\
\hline 発生時刻 & $2004.1 .614: 50$ & $2000.10 .311: 42$ & $2004.9 .820: 58$ \\
震源緯度 & $34.215^{\circ} \mathrm{N}$ & $34.287^{\circ} \mathrm{N}$ & $33.117^{\circ} \mathrm{N}$ \\
震源経度 & $136.714^{\circ} \mathrm{E}$ & $136.342^{\circ} \mathrm{E}$ & $137.287^{\circ} \mathrm{E}$ \\
震源深さ & $37 \mathrm{~km}$ & $44 \mathrm{~km}$ & $36 \mathrm{~km}$ \\
走向 & $30^{\circ}$ & $205^{\circ}$ & $239^{\circ}$ \\
傾斜 & $85^{\circ}$ & $45^{\circ}$ & $37^{\circ}$ \\
すベり角 & $-10^{\circ}$ & $60^{\circ}$ & $54^{\circ}$ \\
地震モーメント & $1.4 \times 10^{17} \mathrm{~N} \mathrm{~m}$ & $8.5 \times 10^{17} \mathrm{~N} \mathrm{~m}$ & $2.3 \times 10^{19} \mathrm{~N} \mathrm{~m}$ \\
& $\left(M_{\mathrm{w}}=5.4\right)$ & $\left(M_{\mathrm{w}}=5.9\right)$ & $\left(M_{\mathrm{w}}=6.8\right)$ \\
コーナー振動数 & $0.8 \mathrm{~Hz}$ & $0.5 \mathrm{~Hz}$ & $0.1 \mathrm{~Hz}$ \\
\hline
\end{tabular}

\section{表 3 東南海地震の震源モデルの諸元}

\begin{tabular}{|c|c|c|}
\hline \multirow[t]{8}{*}{ 全体 } & 面積 & $15800 \mathrm{~km}^{2}$ \\
\hline & 地震モーメント & $\begin{array}{l}2.45 \times 10^{21} \mathrm{~N} \mathrm{~m} \\
\left(M_{\mathrm{w}}=8.2\right)\end{array}$ \\
\hline & 平均すべり量 & $3.8 \mathrm{~m}$ \\
\hline & 応力降下量 & $3.0 \mathrm{MPa}$ \\
\hline & $\mathrm{S}$ 波速度 & $3.82 \mathrm{~km} \mathrm{~s}^{-1}$ \\
\hline & 平均密度 & $2800 \mathrm{~kg} \mathrm{~m}^{-3}$ \\
\hline & 剛性率 & $41 \mathrm{GPa}$ \\
\hline & 破壊伝播速度 & $2.7 \mathrm{~km} \mathrm{~s}^{-1}$ \\
\hline \multirow{4}{*}{$\begin{array}{l}\text { アスペリティ } \\
\text { (西側) }\end{array}$} & 面積 & $1308 \mathrm{~km}^{2}$ \\
\hline & 地震モーメント & $4.26 \times 10^{20} \mathrm{~N} \mathrm{~m}$ \\
\hline & 平均す心゙り量 & $7.9 \mathrm{~m}$ \\
\hline & 応力降下量 & $21.9 \mathrm{MPa}$ \\
\hline \multirow{4}{*}{$\begin{array}{l}\text { アスペリティ } \\
\text { (中央) }\end{array}$} & 面積 & $1107 \mathrm{~km}^{2}$ \\
\hline & 地震モーメント & $3.31 \times 10^{20} \mathrm{~N} \mathrm{~m}$ \\
\hline & 平均すべり量 & $7.3 \mathrm{~m}$ \\
\hline & 応力降下量 & $21.9 \mathrm{MPa}$ \\
\hline \multirow{4}{*}{$\begin{array}{l}\text { アスペリティ } \\
\text { (東側) }\end{array}$} & 面積 & $1107 \mathrm{~km}^{2}$ \\
\hline & 地震モーメント & $3.31 \times 10^{20} \mathrm{~N} \mathrm{~m}$ \\
\hline & 平均すべり量 & $7.3 \mathrm{~m}$ \\
\hline & 応力降下量 & $21.9 \mathrm{MPa}$ \\
\hline \multirow[t]{4}{*}{ 背景 } & 面積 & $11800 \mathrm{~km}^{2}$ \\
\hline & 地震モーメント & $1.29 \times 10^{21} \mathrm{~N} \mathrm{~m}$ \\
\hline & 平均すべり量 & $2.7 \mathrm{~m}$ \\
\hline & 応力降下量 & $2.4 \mathrm{MPa}$ \\
\hline
\end{tabular}

は, 2003 年に内閣府中央防災会議 ${ }^{18)}$ の地震被害想定において用いら れた東南海地震のモデルを使用した。表 3 に震源モデルの諸元を示 す. 図 1 (b) において, 色付の要素断層はアスペリティを, 白色の要 素断層は背景領域を示している。波形合成の際に経験的グリーン関 数として用いる小地震は, 表 2 に示した地震 1 と同じものを用いる こととした.

3 次元有限差分法による地震動の計算は, Graves の食い違い格子 19) およびLevander $の 4$ 次差分 ${ }^{20)}$ による定式化に基づいて行った．格 子形状は地表から深さ $10 \mathrm{~km}$ までは一辺 $150 \mathrm{~m}$, それ以深は一辺 450 

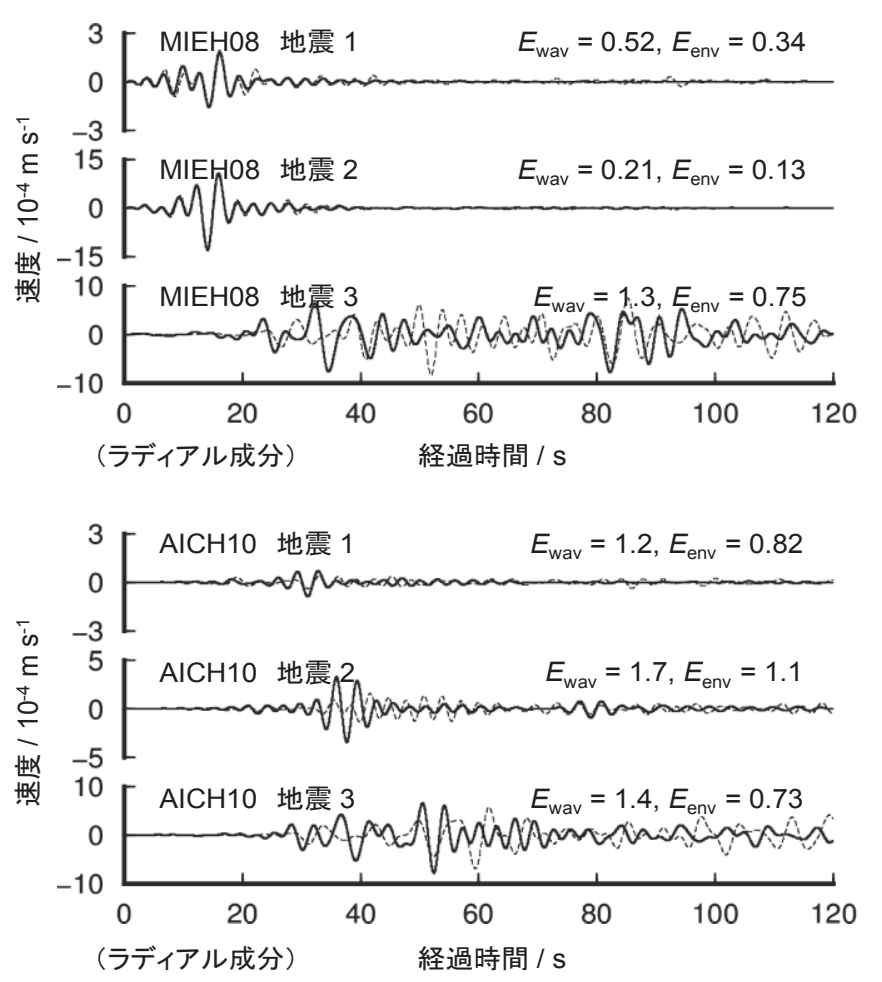

理論計算
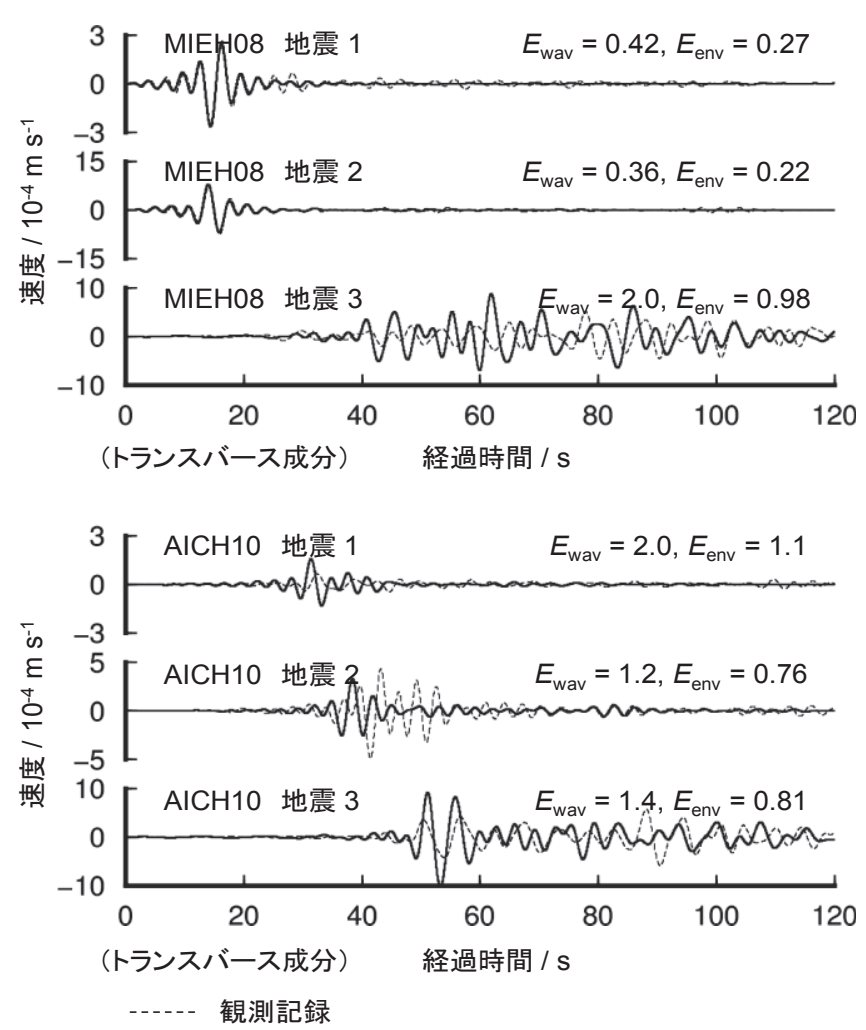

図 43 次元有限差分法によって計算された地震動

$\mathrm{m}$ の立方体形とし, Aoi and Fujiwara の不連続格子を用いた計算方法 21) を採用した。有効周期は $1.9 \mathrm{~s}$ 以上である。計算領域端部には Cerjan et al.のエネルギー吸収境界条件 ${ }^{22)}$ を適用した. 震源の表現 としては, Pitarka による応カテンソルを用いてモーメントテンソル を表現する方法 ${ }^{23)}$ を取った. 非弾性減衰については, 振動数に比例 する $\mathrm{Q}$ 值を考慮しており, 表 1 に示した基準 $\mathrm{Q}$ 值は振動数 $1 \mathrm{~Hz}$ で のQ值を表している. なお, 図 3 より, 観測記録のシグナルノイズ比 が十分に確保されている範囲は低振動数側で $0.1 \mathrm{~Hz}$ 程度以上である ことが分かる. 有限差分法による計算の有効周期とともに余裕をみ て, 以降の検討では周期 $3 \mathrm{~s} \sim 10 \mathrm{~s}$ を対象に考察を行う.

\section{4. 結果と考察}

\subsection{3 次元有限差分法による地震動の計算結果}

はじめに, 表 2 に示した 3 地震による地震動を, 3 次元有限差分法 を用いて計算した. 図 4 に, 計算された速度波形を各地震での観測 波形記録と比較して示寸. すべて周期 $3 \mathrm{~s} \sim 10 \mathrm{~s}$ の帯域通過フィル 夕を施した. 図中の $E_{\mathrm{wav}}$ は計算された波形 $u_{\mathrm{cal}}(t)$ と観測波形 $u_{\mathrm{obs}}(t)$ との不一致の度合いを表す值であり，次式で定義される。

$$
E_{\mathrm{wav}}=\sqrt{\int_{0}^{T}\left[u_{\mathrm{cal}}(t)-u_{\mathrm{obs}}(t)\right]^{2} d t / \int_{0}^{T}\left[u_{\mathrm{obs}}(t)\right]^{2} d t}
$$

また, $E_{\mathrm{env}}$ は包絡形状の不一致の度合いを表す值であり, 各波形の包 絡形状に対して式 (12) と同様の計算を行ったものである.

図 4 より, MIEH08 地点では, 地震 1 および地震 2 の波形がほぼ再 現されていることが分かる. 地震 3 については, 初動の時刻と全体 的な振幅は表現できているが，波形の山谷はずれている。これは， 地震 3 が MIEH08 地点から遠く離れているため, 誤差が蓄積し, 波 形を完全に再現することが困難であることを示している. AICH10
地点では, 各地震ともに初動と全体的な振幅および継続時間は表現 できているが, やはり波形の山谷はずれている.これは, $E_{\mathrm{wav}}$ は大き いが $E_{\mathrm{env}}$ が小さいことにも表れている.

\section{2 伝達関数による地震動の補正}

本論文で提案する伝達関数を用いた地震動の補正の有効性につい て, 表 1 に示した地震 1 による地震動記録から地震 2 による地震動 を推定することで検証する. 図 5 に，地震 2 について，理論計算のみ による地震動, 壇・佐藤の方法 (以下, 従来法と称する) によって地 震 1 から推定された地震動, 本手法によって地震 1 から推定された 地震動を示す，それぞれ，実現象との比較のために，地震動の観測 記録を重称て示した. 同椂に, 図 6 に地震 3 による地震動を推定し た結果を示す.波形の推定にあたっては, 各地震を点震源として扱 い, 伝達関数による補正を行った。

図 5 より, MIEH08 における地震 2 による地震動は, どの手法によ ってもおおむね再現できることが分かる，ただし従来法では，放射 特性の変化を考慮していないため, 波形の正負が逆になっている. AICH10 における地震 2 による地震動は, 全体として初動と全体的 な振幅の程度は合うが，やはり波形の山谷はずれているところが多 い. 包絡形状の一致の程度は, 従来法とほぼ同様であり, 特に本手 法が有利であるというわけではない.

地震 3 による地震動については, MIEH08・AICH10 の両地点にお いて，どちらかというと本手法による推定結果が従来法と比較して 観測記録に近いことが分かる。一方，従来法による推定波形は，全 体として本手法によるものと同程度の振幅となっている.これにつ いては, 後述の伝達関数とフーリエスペクトルも含めて, 4.3 節にお いて考察を行う。 

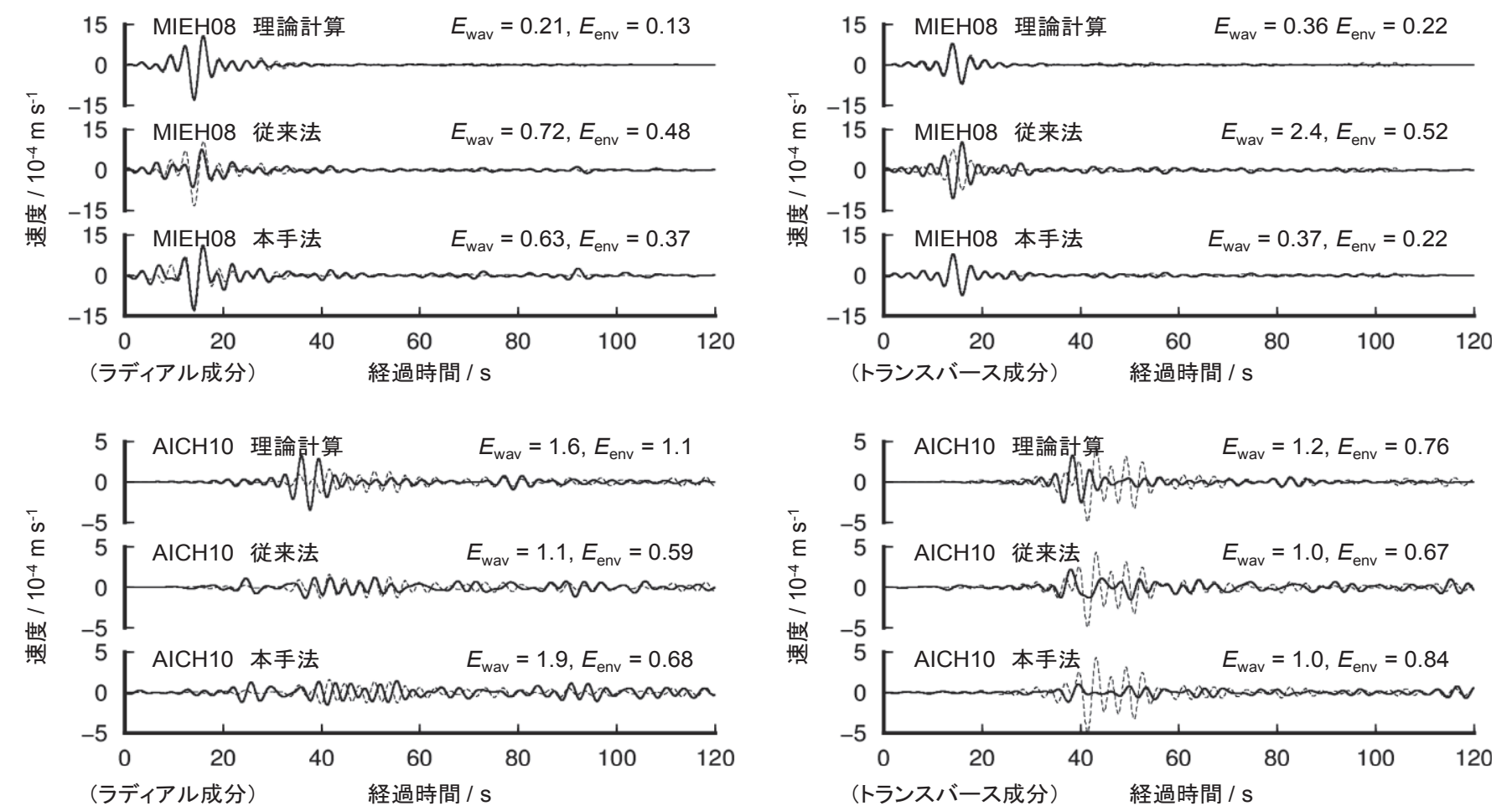
（トランスバース成分）＼cjkstart経過時間/s

各グラフ上部に記載

----- 観測記録

図 5 地震 1 による地震動の観測記録から推定した地震 2 による地震動
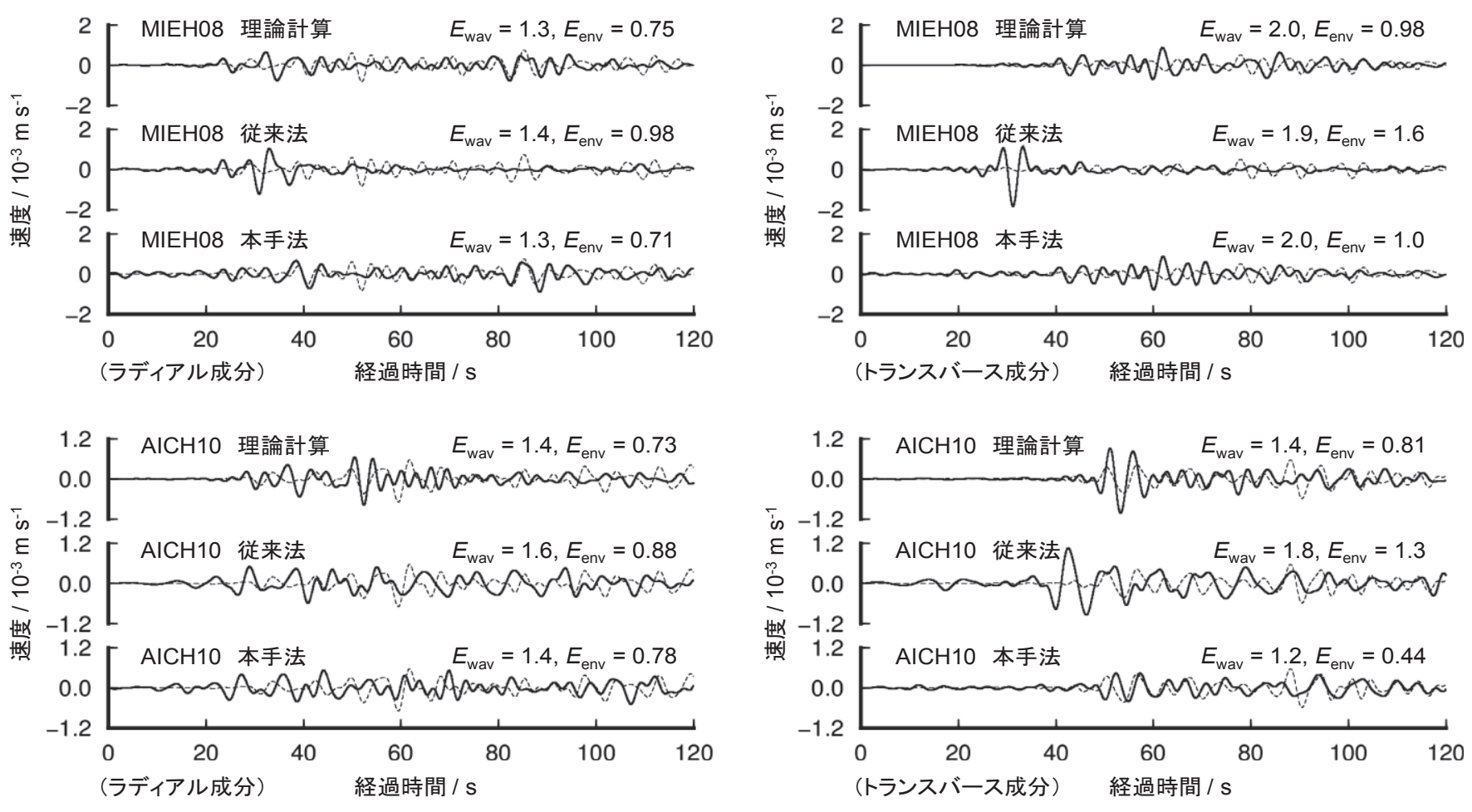

— 各グラフ上部に記載

-.--- 観測記録

図 6 地震 1 による地震動の観測記録から推定した地震 3 による地震動

図 7 に, 地震 1 から地震 2 および地震 3 の地震動を推定するとき の伝達関数を示す. 本手法による伝達関数は, 本論文において対象 とする周期 $3 \mathrm{~s}$ から $10 \mathrm{~s}$ まで (振動数 $0.1 \mathrm{~Hz}$ から $0.33 \mathrm{~Hz}$ まで, 網掛 けを施していない領域) で, 観測記録の伝達関数におお拈む一致し ている. また, 震源同士の距離によるものか, 地震 1 と地震 2 との伝
達関数の方が, 地震 1 と地震 3 との伝達関数と比較して, 観測記録 による伝達関数に近い.

図 8 に, 地震 2 および地震 3 による地震動のフーリエスペクトル 振幅を示寸. 地震 2 については理論計算・従来法・本手法ともにお おむ敞近い值となっている. 地震 3 についても同様である. 対象周 

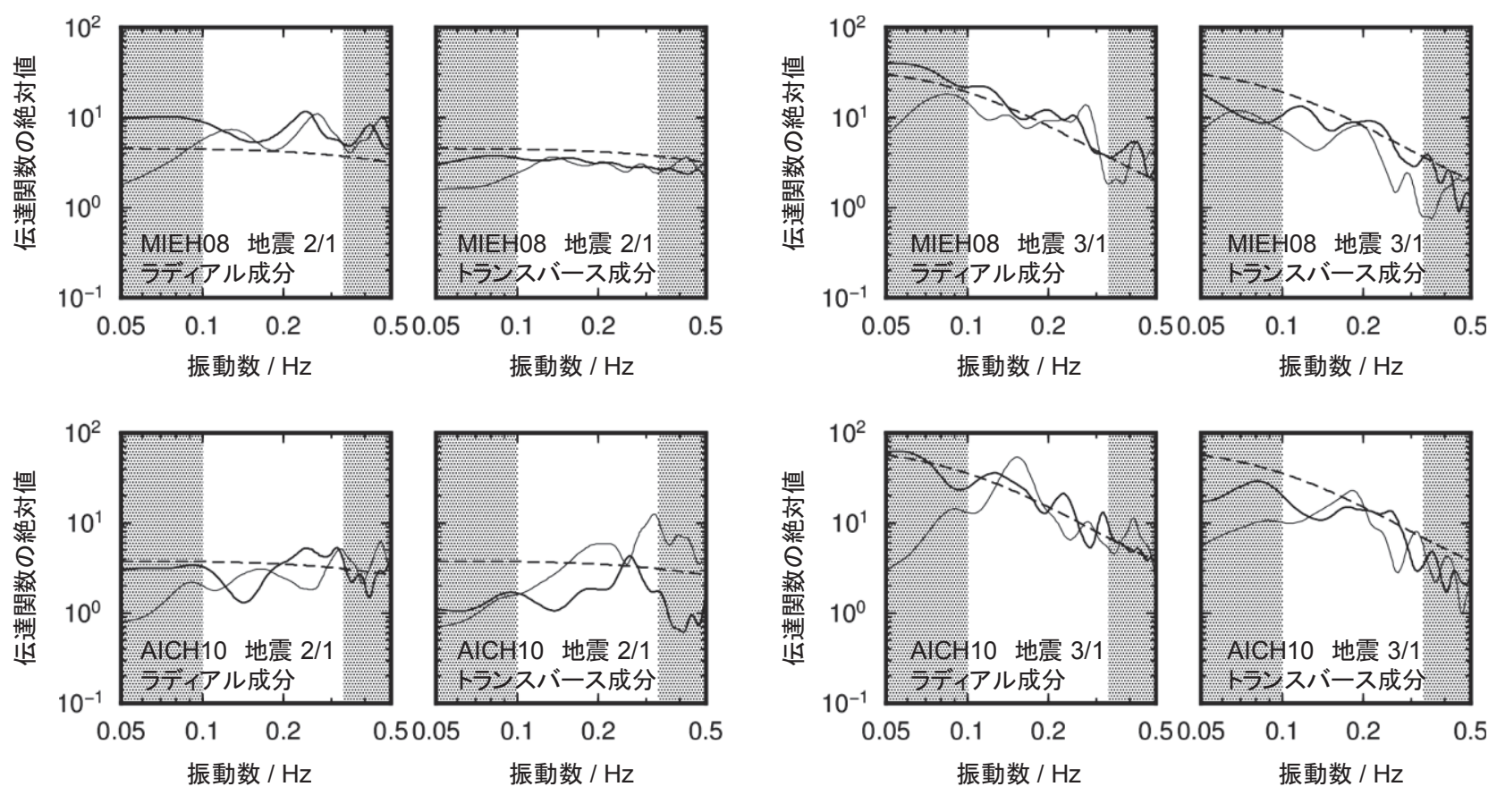

— 本手法 ----- 従来法 —— 観測記録

図 7 地震 1 による地震動記録から地震 2 または地震 3 による地震動を推定するための伝達関数
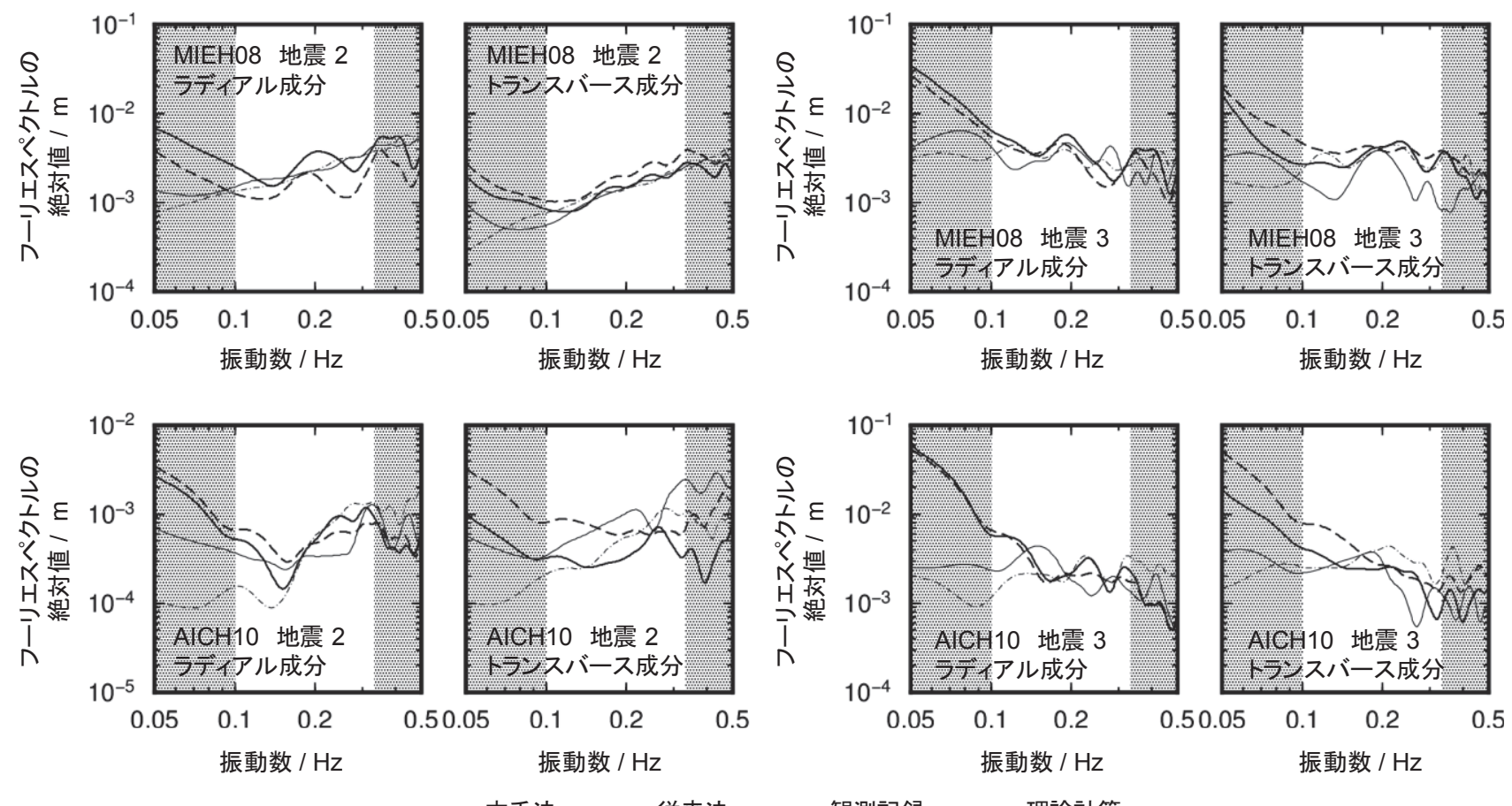

一 本手法 - - - 従来法

観測記録 …… 理論計算

図 8 地震 2 および地震 3 による地震動のフーリエスペクトル

期範囲でフーリエスペクトル振幅の值が近いことは, 四 6 において 理論計算・従来法・本手法による波形が同程度の振幅を示している ことに対応している.

\section{3 地震 3 の波形推定結果における従来法と本手法の関係}

従来法による地震動波形の距離補正は, 主に主要動を合成する目 的から，震源距離に反比例する距離減衰を仮定している。一方，本
手法による補正では，長周期带域には表面波の寄与が大きいことか ら, 一概にはいえないものの, 震源距離の $0.5 \sim 1$ 乗に反比例する距 離減衰を考慮することに相当すると考えられる．地震 3 は MIEH08 および AICH10 のどちらから見ても，地震 1 よりも遠方に震源を有 する. そのため, 地震 1 の記録をもとに地震 3 による地震動を推定 する場合, 従来法による結果は本手法によるものと比較して小さく なるのが自然である.しかし, 図 6 ・図 7 ・図 8 を見る限り, 従来法 


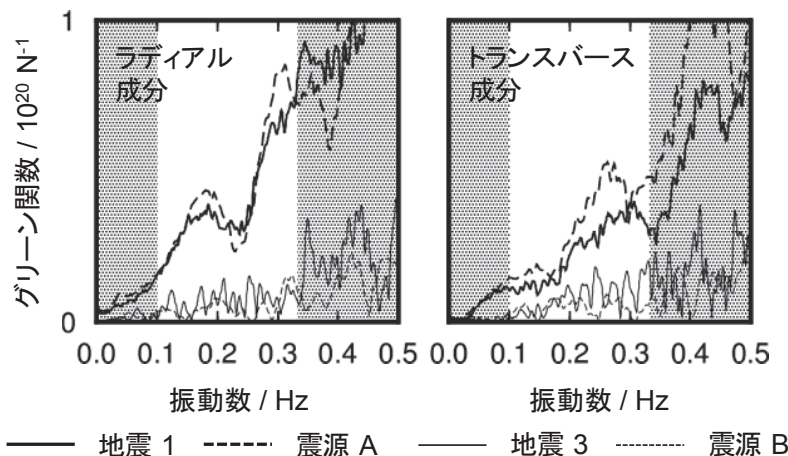

図 9 地震 1,3 および震源 A, B による MIEH08 での地震動を表す グリーン関数のスペクトル

による地震 3 の地震動の推定結果は, 本手法によるものと同程度の 振幅となっている.

有限差分法によって計算されたグリーン関数が正しいと仮定する と, 地震 3 について, 本手法による伝達関数やフーリエスペクトル が観測記録によるそれらと近い值になっている以上, 地震 3 の地震 モーメントやコーナー振動数の推定を誤ったとは考えにくい.する と, 地震 3 による地震動は, 通常よりも減衰が大きいことになる.

このことについて確認するために, 図 2 (a) に示寸通り, MIEH08 から見て地震 1 および地震 3 とは直交する方向に, 地震 1 と同じ距 離に震源 $\mathrm{A}$, 地震 3 と同じ距離に震源 $\mathrm{B}$ を設定し, これらによる MIEH08 での地震動を表すグリーン関数を計算した. 図 9 に, 計算結 果のグリーン関数のフーリエスペクトルを示す. 図 9 より, 地震 1 から地震 3 への減衰量は, 震源 $\mathrm{A}$ から震源 $\mathrm{B}$ 一の減衰量よりも小さ いことが分かる。両方向において異なるのは地盤構造だけであり, 地震 1 と地震 3 との間には付加体を挟んでいることが影響している
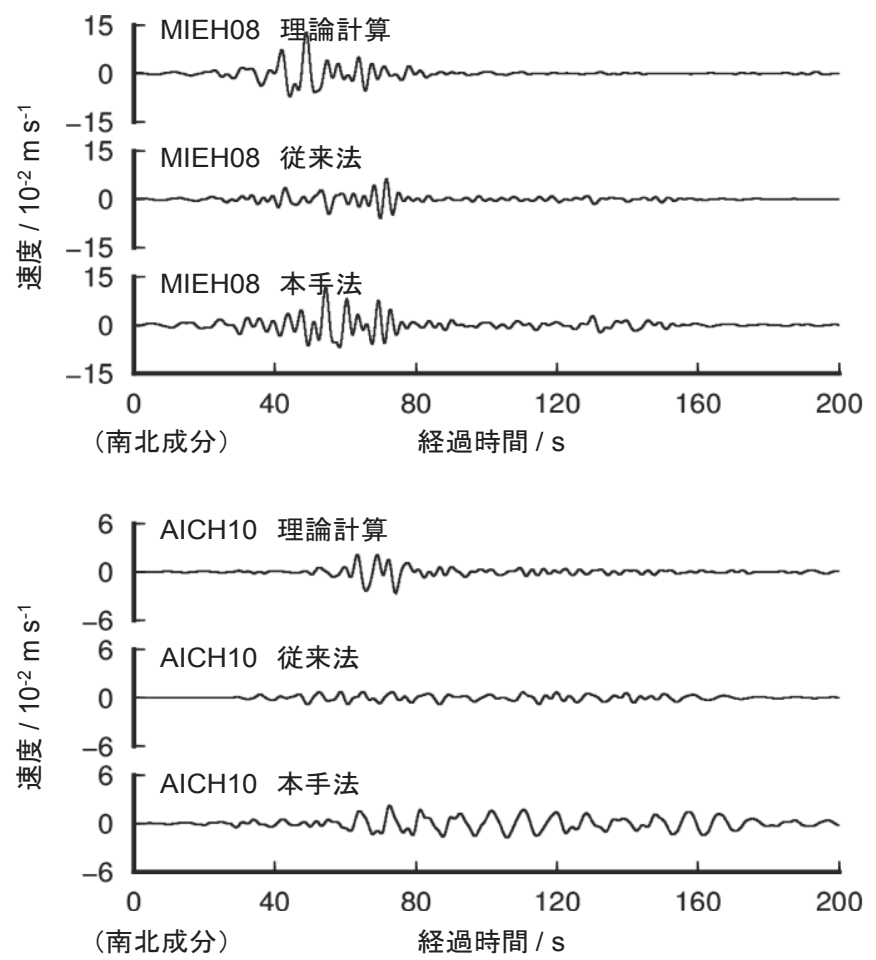

と考えられる. 地震波の伝播における付加体の影響については多く の研究がなされているが, 例えば Furumura et al. は付加体が長周期 地震動をよく伝達することを指摘しており ${ }^{24)}$, 図 9 の結果はこうし た知見と整合する。 そのため, 地震 3 による地震動が，特に通常よ りも減衰量が大きいとは考えにくい.

翻って，地盤構造モデルの減衰が現実よりも大きい，すなわち Q 值が過小評価となっている可能性を考える. 例えば $\mathrm{S}$ 波については, $\mathrm{Q}$ 值による減衰のファクターは $\exp \left(-\omega R / 2 Q V_{\mathrm{s}}\right)$ と表されるため, 震 源距離が長いほど有限差分法によるグリーン関数の過小評価の度合 いが大きい. 本論文では，有限差分法によるグリーン関数によって 観測記録を再現できるように地震モーメントを推定したので，グリ ーン関数が過小評価ならば地震モーメントは過大評価であることに なる.この場合, 図 7 ・図 8 において本手法による伝達関数・フーリ エスペクトルは変化しないが, 従来法によるそれらは過大評価であ り, 本来は本手法による結果よりも小さな值になると考えられる.

定性的には以上のような考察が可能であるが，定量的に検討しよ うとすると, 地盤構造モデルの正確さを検証する必要がある。これ については本論文の範囲を超えるので, 稿を譲ることとする.

\section{4 伝達関数による地震動の補正を用いた波形合成}

伝達関数を用いた地震動の補正方法を波形合成に応用することに ついて, 図 2 (b) に示した東南海地震を例に検討する. 波形合成に 用いる小地震としては, 表 2 に示寸地震 1 を用いた. 図 10 に, 各観 測点における速度波形について, 理論計算のみによる結果, 従来法 による波形合成の結果, 本手法による波形合成の結果を, 周期 $3 \mathrm{~s} \sim$ $10 \mathrm{~s}$ の帯域通過フィルタを施して示す.

図 10 において, 従来法による波形の振幅が小さいのは, 図 6 につ
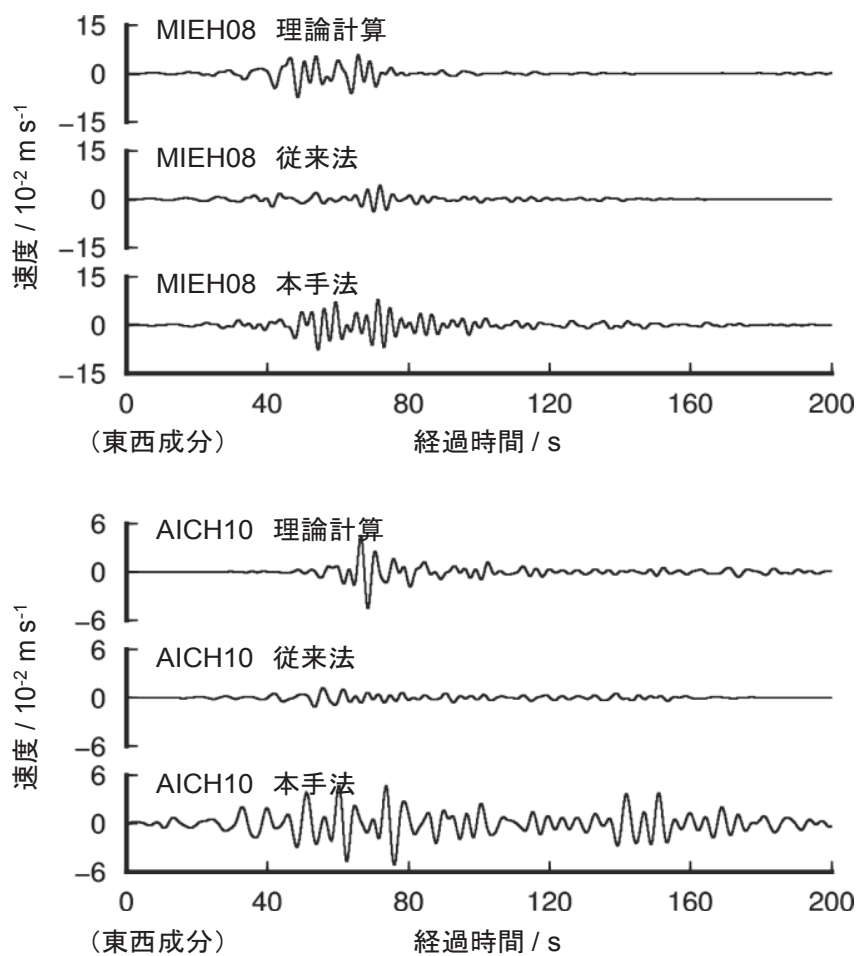

図 10 東南海地震による地震動の計算結果 
いての考察と同様に, 東南海地震による長周期の地震動は主に表面 波によって構成されているのに対して, 従来法では震源距離に反比 例する距離減衰を仮定しているからであると考えられる. 本手法に よる合成波形は, $80 \mathrm{~s}$ 以降の後続波部分の振幅が大きくなっている. これはAICH10地点において特に顕著である. これは, 図4に示した 地震 1 の観測記録において, 理論計算による波形と比較して後続動 が大きく現れていることによる.

本論文のように，波形合成のための経験的グリーン関数として， 想定震源域よりも観測点に近い位置に震源を有する中小地震による 地震動記録を使った場合は, 本手法による地震動は従来法によるも のよりも大きくなる. 逆に, 想定震源域よりも遠方の中小地震によ る地震動を用いる場合は, 従来法による地震動が大きくなる.この ことは, 長周期地震動の影響を受けや寸い高層建物の設計用入力地 震動を作成する際などに, 特に注意を要すると考えられる.

\section{5. まとめ}

本論文では, 経験的グリーン関数法における中小地震による地震 動の補正に適用することを指向して, 地盤構造モデルを用いた理論 計算による地震動のスペクトル比を伝達関数とし, 任意の震源によ る地震動を推定する手法を提案した. また, 多数の要素断層で表現 される大地震に適用寸る場合には, 通常の 3 次元有限差分法によっ て各要素断層による理論地震動を計算することは困難であるので, グリーン関数の相反定理を利用して計算量を削減する方法を取り入 れた. これを 3 つの地震および想定東南海地震の震源モデルに適用 して検証を行った.

従来の波形合成法においては主に主要動を合成する目的から，実 体波の距離減衰特性が仮定されていた。本手法では, 実体波あるい は表面波のみでなく, すべての相を含んだ形で理論的に距離減衰を 補正することが可能である. そのため, 4.4 節で検討を行ったような, 表面波の寄与が大きい長周期地震動の合成を行う場合に, 既存の手 法と比較して有用であると考えられる。一方で, 観測記録のスペク トルに理論地震動のスペクトル比を乗じて地震動の補正を行うため, 震源同士の距離が遠い場合には, 正確さが損なわれる。これは本手 法を広く適用しようとする場合において課題となる点である。

平井・福和 (2013) においても言及されているが, 本手法で用いた 相反定理を利用寸るグリーン関数の計算方法は，あらゆる位置の震 源から観測点への地震動を表すグリーン関数をデータベース化し， 種々の想定地震による地震動を効率よく計算することを可能とする. これに加えて, 本論文で提案した地震動の観測記録を援用する手法 を用いれば，より高精度な地震動の予測を実現することが可能にな ると考えられる。

\section{謝辞}

地震の震源情報として, 気象庁による決定値を用いた. 地震の発 震機構として, 防災科学技術研究所の F-net によるメカニズム解を 用いた. 観測記録との比較においては, 同所の KiK-netによる地震 動記録を使用した。論文中の一部の図の作成に Generic Mapping Tools ${ }^{25)}$ を用いた. また, 本研究で用いられた経費の一部は, 科学研 究費補助金 (課題番号 25889032) の助成によるものである.

\section{参考文献}

1) 中央防災会議：南海トラフ巨大地震対策について (最終報告), 2013.5

2) 気象庁：長周期地震動に関する情報のあり方検討会 (第 1 回) 資料, 2011.11

3) 建築研究所：強震観測 Web, http://smo.kenken.go.jp/ja/smdb/drawwav/ 201103111446SKS, 2011 (2014.6.16 閲覧)

4) 座間信作：気象庁 1 倍強震計記録にみられるやや長周期地震動特性 一 その 2 東京一, 消防研究所報告, 76, pp.1-12, 1993.9

5）植竹富一：広带域地震観測に基づく東京湾岸のやや長周期地震動特性, 第 13 回日本地震工学シンポジウム論文集, pp.4157-4164, 2010.11

6) 湯沢豊, 南雲秀樹：長周期地震動の摇れ易さ係数の変動要因とその低減 対策変動幅に影響を与える要因分析とその対策 一関東平野を例として 一, 日本地震工学会論文集, 12, pp.41-59, 2012.2

7) 寺島芳洋, 高橋広人, 福和伸夫, 護雅史：堆積盆地における地盤と超高 層建物との共振現象に関寸る研究 その 1 大阪平野の地盤周期の分析 と強震動予測, 日本建築学会大会学術講演梗概集, B-2, pp.151, 2012.9

8) Hartzell, S. H. : Earthquake aftershocks as Green's function, Geophys. Res. Lett., 5, pp.1-4, 1978.1

9) 高橋広人, 林宏一, 福和伸夫：擬似経験的グリーン関数法を用いた強震 動予測，応用地質技術年報, 28, pp.15-29, 2008.2

10) Irikura, K. : Semi-empirical estimation of strong ground motion during large earthquakes, Bull. Disas. Prev. Inst., Kyoto Univ., 33, pp.63-104, 1983.6

11) 田中貞二, 吉沢静代, 坂上実, 大沢㭌：小地震記録の合成による強震動 加速度特性の推定, 地震研究所彙報, 57, pp.561-579, 1983.1

12) Irikura, K. : Prediction of strong acceleration motions using empirical Green's function, Proceedings of the 7th Japan Earthquake Engineering Symposium, pp.151-156, 1986.12

13）壇一男，佐藤俊明：断層非一様すべり破壊を考慮した半経験的波形合成 法による強震動予測，日本建築学会構造系論文集, 509, pp.49-60, 1998.7

14) 平井敬, 福和伸夫：3 次元有限差分法と相反定理を用いた堆積盆地の地 盤震動性状の評価手法, 日本建築学会構造系論文集, 第 78 巻, 第 694 号, pp.2083-2092, 2013.12

15）松井孝典, 松浦充宏, 林祥介, 寺沢敏夫, 谷本俊郎, 唐戸俊一郎：地球連 続体力学, 岩波書店, pp.175-183, 2010.10

16）堀川晴央，吉見雅行，関口春子，吉田邦一，杉山雄一，佐竹健治，福和伸 夫, 鈴木晴彦, 松山尚典, 劉瑛, 滝沢文教 : 中京地域の 3 次元地盤構造モ デル, 活断層・古地震研究報告, 8, pp.203-254, 2008.12

17) 防災科学技術研究所：F-net 広带域地震観測網, http://www.fnet.bosai go.jp/ (2014.6.16 閲覧)

18) 中央防災会議：東南海・南海地震等に関する専門調査会 (第 16 回) 資料 3, 2003.12

19) Graves, R. W. : Simulating seismic wave propagation in $3 D$ elastic media using staggered-grid finite differences, Bull. Seismol. Soc. Am., 86, pp.1091-1106, 1996.8

20) Levander, A. R. : Fourth-order finite difference P-SV seismograms, Geophysics, Vol. 53, pp.1425-1436, 1988.11

21) Aoi, S. and Fujiwara, H. : 3D finite-difference method using discontinuous grids, Bull. Seismol. Soc. Am., 89, pp.918-930, 1999.8

22) Cerjan, C., Kosloff, D., Kosloff, R. and Reshef, M. : A non-reflecting boundary condition for discrete acoustic and elastic wave-equations, Geophysics, 50, pp.705-708, 1985.4

23) Pitarka, A. : 3D elastic finite-difference modeling of seismic motion using staggered grid with nonuniform spacing, Bull. Seismol. Soc. Am., Vol. 89, pp.54-68, 1999.2

24) Furumura, T., Hayakawa, T., Nakamura, M., Koketsu, K. and Baba, T. : Development of long-period ground motions from the Nankai Trough, Japan, Earthquakes: Observations and computer simulation of the 1944 Tonankai (Mw 8.1) and the 2004 SE Off-Kii Peninsla (Mw 7.4), Pure Appl. Geophys., 165, pp.585-607, 2008.3

25) Wessel, P., Smith, W. H. F., Scharroo, R., Luis, J. F., and Wobbe, F. : Generic Mapping Tools: Improved version released, EOS Trans. AGU, 94, pp.409-410, 2013.11 


\title{
PREDICTION METHOD OF LONG-PERIOD GROUND MOTION \\ FOR ARBITRARY SEISMIC SOURCE \\ USING TRANSFER FUNCTION BASED ON SOIL STRUCTURE MODEL
}

\author{
Takashi HIRAI* and Nobuo FUKUWA** \\ * Assist. Prof., Graduate School of Environmental Studies, Nagoya University, Dr. Eng. \\ ** Prof., Disaster Mitigation Research Center, Nagoya University, Dr. Eng.
}

Many large earthquakes have occurred in and around Japan, since the Japanese islands are located at the plate convergent area. Especially in the Nankai Trough, where the Philippine Sea plate is subducting under the Eurasian plate, large earthquakes have occurred at intervals of about 100 to 150 years. The last Nankai Trough Earthquakes were the 1944 Tonankai Earthquake and the 1946 Nankai Earthquake. Now South-West Japan faces the danger of the next Nankai Trough Earthquake. Long-period ground motion is one of the problems in a large earthquake. It causes the vibration of high-rise buildings and long-span bridges, the sloshing of tanks, etc. Therefore, it is important for reduction of seismic damage to predict the characteristics of the long-period ground motion due to the large earthquake.

Empirical Green's function method is considered to be the most accurate method to predict ground motion. In the pseudo-empirical Green's function method, the transfer function defined as the spectral ratio of the theoretical ground motions between at arbitrary site and at the ground motion observation point is used to accurately predict the long period ground motion at the site.

In this study, the scheme of the pseudo-empirical Green's function method is applied to the seismic source. In the empirical Green's function method, the ground motion record is scaled up to the elemental ground motion under the assumption of body wave. However, the long-period ground motion mainly consists of surface wave. In our method, the transfer function defined as the spectral ratio of theoretical ground motions between by elemental fault and by the observed seismic source is used to estimate the ground motion by elemental fault. Theoretical ground motion is computed by the finite difference method based on the soil structure model. Multiplying the transfer function and the observed ground motion by the small earthquake, ground motion by the elemental fault is estimated with appropriate factors for each phase, such as $\mathrm{P}$ wave, $\mathrm{S}$ wave, and surface wave. Furthermore, a technique to compute the Green's functions giving the ground motions at a station by arbitrary seismic sources based on the reciprocity theorem is used in order to reduce calculation load

Applying the new method to three earthquakes, it was suggested that the ground motion record of a small earthquake is accurately scaled up to that of a large earthquake. In addition, the ground motion by the future Tonankai Earthquake is estimated by the new method. According to the result, the ground motion due to the future Tonankai earthquake is predicted greater by the our method than by the existent method. The difference is caused by using near seismic source as the empirical Green's function. Since the distance dependency of surface wave is mainly applied in our method, it becomes smaller than that by the existent method, which uses the distance dependency of body wave. Conversely, the amplitude becomes smaller by our method relative to the existent method if a far earthquake is employed as the empirical Green's function. This result is important for high-rise buildings sensitive to the long period ground motion. 